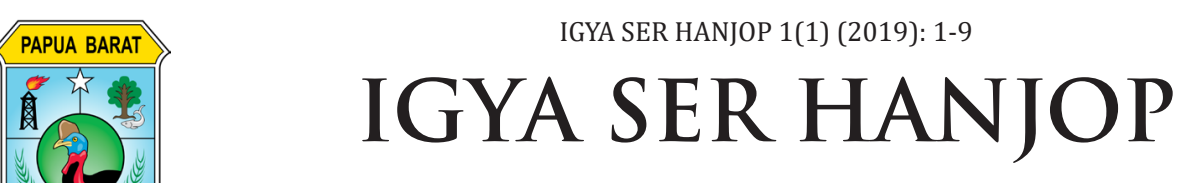

p-ISSN: 2716-0491

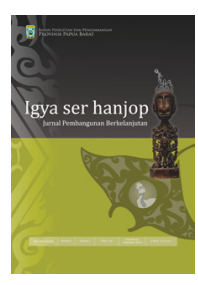

\title{
KONSTRUKSI ETNOTEKNOKONSERVASI \\ BURUNG Pintar (Amblyornis InORNATa) \\ di Kawasan Cagar alam Pegunungan Arfak
}

\author{
Antoni Ungirwalu ${ }^{*}$, Agustina Y.S. Arobaya ${ }^{2}$, M.J. Tokede ${ }^{3}$, Mariana H. Peday ${ }^{4}$, \\ Dina Arung Padang ${ }^{5}$, Susanti Tasik ${ }^{6}$, Zulfikar Mardiyadi ${ }^{7}$, \\ B.M.G. Sadsoetoeboen ${ }^{8}$, O.P. Matani ${ }^{9}$ \\ $1^{*}, 2,3,4,5,6,7,8$ Fakultas Kehutanan Universitas Papua \\ Jl. Gn. Salju, Manokwari Barat, Amban, Manokwari, Papua Barat 98314 \\ ${ }^{9}$ Setda Provinsi Papua Barat \\ Katebu, Manokwari Selatan, Kabupaten Manokwari, Papua Barat. 98315
}

Dikirim: 21 September 2019; Direvisi: 29 Oktober 2019; Disetujui: 18 Desember 2019

\begin{abstract}
Ethnotecnoconservation ideally occurs when humans must repeatedly adjust to the natural system and must allow the forest environment to be present in the minds of the people themselves. This study aims to construct the local wisdom of the Arfak ethnics in the utilization and preservation of Bowerbird in the Arfak Mountains Nature Reserve area. From 9 (nine) clever bird nests found in Mt. Kongoi Mokwam, were found symbols of the local cultural ethics of the Arfak ethnic from the process of adaptation and interaction with the natural environment. The results of the study found that local wisdom in the use and conservation of smart birds is a process of social creation. The adaptation of Arfak's social creation to the environment will produce forms of interaction that initially focus on the use of subsistence fulfillment, then turn to local conservation concepts in the form of a prohibited symbol in the form of animal and plant body parts that are affected by changes in the natural environment and the presence of outsiders in determining changes to the conservation of bowerbirds. The symbolization of the prohibited sign is a manifestation of the Arfak ethnic etnontnoconservation in supporting the concept of "Igya ser Hanjob" which is to maintain the limits of the presence of bowerbirds in the CA Arfak Mountains region as their identity and entity which is still maintained today.
\end{abstract}

Keywords: etnotecnoconservation, bowerbird, Arfak Ethnic, nature reserve

\section{Intisari}

Etnoteknokonservasi secara ideal terjadi ketika manusia secara berulang harus menyesuaikan diri dengan sistem alam dan harus mengizinkan lingkungan hutan hadir dalam pikiran masyarakat itu sendiri. Kajian ini bertujuan untuk mengkonstruksikan kearifan lokal suku Arfak dalam pemanfaatan dan pelestarian burung pintar (Bowerbird) di kawasan Cagar Alam (CA) Pegunungan Arfak. Dari 9 (sembilan) persarangan burung pintar yang ditemukan tersebar di gunung Kongoi Mokwam, ditemukan simbol etika budaya lokal suku Arfak dari proses adaptasi dan interaksi dengan alam lingkungannya. Hasil kajian menemukan bahwa kearifan lokal dalam pemanfaatan dan pelestarian burung pintar merupakan proses kreasi sosial. Adaptasi kreasi sosial masyarakat suku Arfak terhadap lingkungan akan menghasilkan bentuk-bentuk interaksi yang pada awalnya berfokus pada pemanfaatan bagi pemenuhan subsisten, kemudian beralih menjadi konsep pelestarian lokal dalam wujud simbol larangan berupa bagian tubuh hewan dan tumbuhan yang dipengaruhi oleh perubahan lingkungan alam dan kehadiran pihak luar dalam menentukan perubahan terhadap pelestarian burung pintar. Simbolisasi tanda larangan merupakan wujud etnoteknokonservasi suku Arfak dalam mendukung konsep "Igya ser Hanjob" yaitu menjaga batas keberadaan burung pintar di kawasan CA Pegunungan Arfak sebagai identitas dan entitasnya yang masih dipertahankan hingga sekarang.

Kata Kunci: etnoteknokonservasi, bowerbird, Suku Arfak, cagar alam

\footnotetext{
* Korespondensi Penulis

Phone : : +62 81344123400

Email : a.ungirwalu@unipa.acid
}

(C) 2019 Antoni Ungirwalu, Agustina Y.S. Arobaya, M.J. Tokede, Mariana H. Peday, Dina Arung Padang, Susanti Tasik, Zulfika Mardiyadi, B.M.G. Sadsoetoeboen, O.P. Matani.

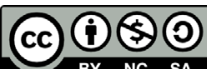

Ciptaan disebarluaskan di bawah Lisensi Creative Commons Atribusi NonKomersial-Berbagi Serupa 4.0 Internasional. 


\section{LATAR BELAKANG}

Masyarakat telah berkembang dengan lingkungannya dalam mempertahankan pengetahuan ekologi dan budaya lokalnya (Karpouzoglou \& Zimmer, 2016; Liu et al., 2010; Ungirwalu et al., 2018). Awal mula dari berbagai kajian ekologi-budaya dan studi antropologi ekologi di masa kini sebenanya telah digagas sejak tahun 1930-an oleh Julian H. Steward, dalam esainya yang berjudul "The Economic and Social Basis of Primitive Bands" pada 1936 yang mendiskripsikan secara utuh mengenai "bagaimana interaksi antara kebudayaan dan lingkungan dapat dianalisis dalam kerangka hubungan sebab-akibat (in causal terms), tanpa harus terjebak dalam "partikularisme" serta dimana analisis kebudayaan yang dilakukan hanya relevan pada inti kebudayaan itu saja (Steward, 1936).

Kritik teori Steward (1936) kemudian mengusulkan teori lain untuk menelaah hubungan manusia dengan lingkungannya. Teori baru tersebut merupakan suatu pendekatan yang diyakini akan mengarahkan cara berpikir sistem yang merujuk pada "ekologi". Konsep ekologi menekankan saling ketergantungan antar kelompok organisme hidupyang merupakan suatu komunitas dengan keadaan lingkungan alam yang bersangkutan (Geertz, 1983).

Etnoteknokonservasi merupakan bagian dari kajian ekologi-budaya, yaitu sebuah cara pandang baru yang berkembang dalam memahami masalah lingkungan hidup menurut nilai-nilai budaya atau bagaimana memahami budaya masyarakat dalam sudut pandang lingkungan hidup. Metode pendekatan etnoteknokonservasi dalam kajian ini lebih banyak dipengaruhi oleh tulisan para etnosains (Ethnoscience), dan pertama kali diperkenalkan oleh Harold C. Conklin (1955) serta didukung oleh Charles O. Frake (1968) dalam sebuah simposium yang berjudul "Ecology and Anthropology" dengan paper berjudul "Cultural Ecology and Ethnography". Selanjutnya kemunculan etnoekologi yang dicetuskan oleh ahli antropologi dengan latar belakang linguistik yang kuat seperti Ward Goodenough tahun 1957.

Tujuan etnoekologi secara umum adalah melukiskan lingkungan sebagaimana dipresepsikan oleh masyarakat yang diteliti. Oleh karena itu untuk memahami lingkungan budaya, seseorang harus mengungkapkan taksonomi-taksonomi, klasifikasi-klasifikasi, terminologi-terminologi lokal. Sebab dalam taksonotni, klasifikasi dan terminologi inilah terkandung pernyataan-pernyataan atau ide-ide masyarakat yang diteliti mengenai lingkungan budayanya.

Di Papua, masih begitu banyak fenomena lingkungan budaya yang perlu dieksplorsi secara mendalam mengingat keragaman budaya yang multi etnis masyarakat Papua dengan persepsi dan terminologi yang berbeda pula. Di antaranya adalah pada tatanan kebudayaan suku besar Arfak di Papua Barat, suatu komunitas masyarakat lokal yang terdiri atas suku (etnis) Hatam, Meyakh, Moile dan Sougb. Secara ekologi-budaya mereka telah mengenal terminologi pembagian wilayah hutan berdasarkan karakter biofisik alam seperti elevasi, topografi dan iklim serta aturan pemanfaatannya.

Hutan pada Kawasan Pegunungan Arfak tidak hanya sekadar dijadikan sumber penyedia bagi pemenuhan kebutuhan subsisten masyarakat, tetapi juga sebagai wadah proses belajar informal masyarakat lokal untuk menemukan pengetahuan dan pandang baru dalam konteks perlindungan dan pengawetan sumberdaya alam menurut perkembangan peradaban mereka yang dijadikan sebagai konsep etnoteknokonservasi. Selain spesies tumbuhan yang banyak dimanfaatkan, terdapat pula spesies burung endemik seperti cenderawasih hitam (Porotia sefillata), cenderawasih belah rotan (Cicinnurus magnificus) dan burung pintar atau Bowerbird (Amblyornis inornata) yang dilindungi oleh masyarak lokal menurut konsep konservasi lokal yang dipertahankan sampai saat ini.

Meskipun faktanya bahwa masyarakat telah mempraktikkan secara turun-temurun peraturan dan norma adat tentang penguasaan, pemanfaatan dan pemeliharaan hutan terkait pemanfaatan dan perlindungan terhadap satwa endemik. Namun norma dan nilai kearifan lokal tersebut kurang mendapat pengakuan (recognition) dan penghargaan (compensation) dari pemerintah. Akibatnya, selain model pengelolaan hutan yang diterapkan saat ini belum mampu mengakomodasi kepentingan masyarakat lokal, nilai kearifan lokal mereka juga berangsur-angsur semakin terlupakan. Apakah wujud kearifan lokal tentang konservasi burung pintar bagi masyarakat suku 
Arfak masih ada hingga generasi sekarang? Pertanyaan ini yang menjadi pertanyaan utama yang perlu dikonstruksi menjadi sebuah jawaban dalam kajian ini.

Tujuan kajian ini adalah untuk mengkonstrusikan kearifan lokal suku Arfak dalam etnoteknokonservasiuntuk pemanfaatan dan pelestarian burung pintar (Bowerbird) di Kawasan CA Pegunungan Arfak. Diharapkan dari kajian ini dapat menambah khasanah pengetahuan tentang kearifan lokal etnis di Papua sekaligus menjembatani diskursus dari proses pemanfaatan SDA dalam merumuskan kebijakan pengelolaan khususnya hutan untuk kawasan fungsi lindung dan konservasi di Papua.

\section{METODE}

\section{a) Lokasi dan Waktu Penelitian}

Penelitian ini dilaksanakan selama satu bulan di dua kampung, yaitu kampung Syoubri dan kampung Kwau Distrik Warmare Kabupaten Manokwari. Obyek penelitian adalah mengkonstruksi wujud kearifan suku Arfak dalam melestarikan habitat dan burung endemik lokal di Hutan Mokwam kawasan CA Pegunungan Arfak.

\section{b) Metode Penelitian}

Metode penelitian adalah metode dekriptif menggunakan pendekatan etnografi kognitif guna memperoleh penjelasan sosiologis interaksi sosial budaya dan kearifan lokal dalam melestarikan habitat burung pintar (Bowerbird) sebagai satwa endemik lokal khas pegunungan Arfak.

\section{c) Teknik Pengambilan Contoh}

Pengaambilan contoh untuk lokasi kawasan hutan dan masyarakat suku Arfak ditentukan secara purposif. Kawasan hutan Mokwam dipilih merupakan habitat persarangan burung pintar dan telah menjadi daerah tujuan wisata alam khusus obyek wisata pengamatan burung pintar khas pegunungan Arfak. Sementara responden utama adalah masyarakat suku Arfak di kampung Syoubri dan kampung Mokwam yang dipilih sebagai pelaku utama dan diketahui masih menerapkan kearifan lokal dalam melindungi dan melestarikan burung pintar dan habitat persarangannya.

\section{d) Teknik Pengumpulan Data}

Teknik pengumpulan data dilakukan dengan pendekatan etnografi yang dikembangkan oleh Spradley (1997) yang mengkombinasikan teknik pengamatan terlibat (Partisipative observation) non struktural dengan tehknik "Snowball" dan studi literatur. Jenis data yang dikumpulkan meliputi kondisi fisik habitat sarang serta proses simbolisasi perlindungan sarung pintar dan persarangannya. Variabel pengamatan dalam kajian ini adalah kontruksi kearifan lokal etno-tekno-konservasi suku Arfak dari proses pemanfaatan dan pelestarian khususnya pada habitat burung pintar (Bowerbird).

\section{e) Analisis Data}

Data hasil pengamatan dianalisis secara deskripttif kualitatif berdasar klasifikasi dan dikontruksikan secara simbolik sesuai sudut pandang pengetahuan sosial budaya yang berlaku di masyarakat Arfak. Selanjutnya disistematisasi dan diinterpretasikan berdasarkan nilai-nilai konservasi yang terkandung di dalamnya dengan fokus pelindungan, pengawetan dan pemanfaatan burung pintar, habitat dan persarangan secara lestari di CA Pegunungan Arfak.

\section{HASIL DAN PEMBAHASAN}

\section{A. Konstruksi Etnoteknokonservasi Suku Arfak}

Laksono dkk, (2004) mengungkapkan pembagian wilayah hutan di Pegungan Arfak yang dikenal dengan konsep "Igya ser hanjob" dari bahasa Hatam yang secara harfiah berarti "kita berdiri menjaga batas" Konsep ini merupakan peraturan dan peringatan bagi masyarakat suku besar Arfak yang diatur secara informal dan bertujuan untuk menjaga dan tidak melewati batas-batas wilayah yang ditentukan pada saat memanfaatkan hasil hutan. Konsep "Igya ser hanjob" diartikan secara luas oleh masyarakat lokal dengan semboyan "mari kita menjaga hutan untuk kepentingan bersama" merupakan bagian dari interaksi dan adaptasi dengan lingkungan hutan khususnya di kawasan Cagar Alam (CA) Pegunungan Arfak.

Kawasan konservasi CA Pegunungan Arfak adalah kawasan tempat berinteraksinya masyarakat lokal Arfak, jauh sebelum kawasan 
itu ditetapkan pemerintah. Interaksi suku Arfak dengan lingkungan hutan yang sudah terjalin sejak lama dan telah menghasilkan sejumlah bentuk strategi interaksi dan beradaptasi dengan lingkungan alamnya dalam memperoleh sumber makanan dan minuman, mengatasi kondisi fisik lingkungan, mempertahankan hidup, bereproduksi, dan merespon perubahan yang terjadi di sekitarnya. Termasuk diantaranya adalah memanfaatkan dan melestarikan sumber daya hayati endemik yang terkandung di CA Pegunungan Arfak.

Dalam lingkungan ekologi-budaya di Papua Barat, kearifan lokal dijumpai dalam berbagai simbol-simbol artefak yang bersifat abstrak.Kearifan lokal dalam suatu komunitas masyarakat dapat muncul secara alami, namun kearifan tersebut ada pula yang muncul karena "social creation", tercipta sebagai hasil dari pemikiran manusia dalam kebudayaan yang dimiliki sebagai perwujudan peran-peran dari interaksi sosial dalam ruang, waktu dan tempat. Struktur sosial sebagai jaringan hubungan dan relasi-relasi yang nyata diantara individu atau kelompok individu dalam masyarakat (Mansoben, 1995; Radcliffe-Brown, 2008). Relasi dalam budaya dapat ditimbulkan oleh faktor sejarah, lingkungan, dan psikologis yang berbeda (Kaplan \& Manners, 1999).

Konstruksi simbolis daya tarik burung pintar dan persarangannya mulai diterjemahkan oleh masyarakat asli suku Arfak dalam bentuk pengetahuan sebagai wujud pemahaman mereka terhadap sumberdaya di sekitarnya. Hasil interaksi mereka dengan alam pada awalnya melalui aktivitas berburu hewan liar telah membentuk pengetahuan lokal (etnosains) dari beberapa anggota suku Arfak tentang keunikan sumberdaya alam tersebut. Salah satu pionirnya adalah Zeth Wonggor seperti warga lokal lainnya yang hidup berinteraksi dan beradaptasi dengan alam guna memenuhi kebutuhan hidup sehari-hari sebagai pemburu. Berburu atau Matomarok (bahasa sub etnis Sougb) merupakan kagiatan dalam rangka pemenuhan kebutuhan protein hewani yang dilakukan secara berkelompok dengan menggunakan peralatan tradisional yaitu tombak, panah, parang, dan jerat dan biasanya menggunakan bantuan anjing untuk mengejar dan menagkap buruan (Laksono et al., 2004).

Keseharian berinteraksi dengan alam menjadikan mereka mampu beradaptasi dengan perilaku dan perubahan alam untuk menghasilkan pengalaman yang nantinya akan terkonstruksi dalam wujud pengetahuan. Kemampuan dalam memahami lokasi habitat dan perilaku satwa buruan baik burung maupun satwa liar lainnya merupakan bentuk kontruksi pengetahuan lokal melalui presepsi yang terus menerus dan berulang hingga diyakini kebenaarannya. Bagi Zeth Wonggor kemampuan dan keahlian berburu serta pengetahuannya tentang perilaku satwa buruan yang melebihi di atas rata-rata masyarakat lokal lainnya, menyebabkan ia selalu memperoleh hasil buruan yang paling banyak di antara para pemburu lainnya (Agustono, 2014).

Pengetahuan yang berkembang dalam masyarakat lokal sebagai suatu sistem pemaknaan terhadap fenomena alam kemudian dipelajari, diperbaiki, dipertahankan dan didefinisikan kembali dalam konteks interaksional (Rudito \& Famiola, 2008; Spradley, 1997). Pengetahuan lokal pemanfaatan dan pelestarian tersebut dapat dikonstruksikan sebagai dasar ilmu pengetahuan kehutanan (cientific forestry) berbasis komunitas masyarakat adat di Papua.

Etnoteknokonservasi secara ideal terjadi ketika manusia secara berulang harus menyesuaikan diri dengan sistem alam dan harus mengizinkan lingkungan hutan hadir dalam pikiran masyarakat manusia sendiri. Kemampuan masyarakat suku Arfak dalam menerapkan etnoteknokonservasi Bowerbird adalah bagian dari etika lahan "land etics" (Leopold, 2004). Pola aktivitas berburu dan pemikiran ekologis yang menempatkan faktor moralitas manusia sebagai yang utama dengan merubah eksploitasi pemanfaatan (berburu) menjadi adaptasi pelestarian (menjaga) SDA dijadikan standar etika di masyarakat. Kesadaran dari pola pemanfaatan satwa burung menjadi pola pelestarian burung adalah proses kesadaran yang terbangun karena interkasi dengan pihak luar, terutama para wisatawan, LSM dan para pemerhati lingkungan yang berkunjung pada wilayah ini. Selanjutnya etnoteknokonservasi diwujudkan dalam tanda larangan sebagai simbol yang secara filosofis Igya ser hanjob yaitu menjaga batas sekaligus melindung satwa dan persarangan yang ada.

Penggunaan simbol-simbol etika budaya dalam etnoteknokonservasi terhadap 
pelestarian burung pintar di Mokwam adalah wujud hasil pengetahuan lokal (etnologi) yang terbangun dalam komunitas masyarakat suku Arfak. Simbol adalah obyek atau peristiwa apapun yang menunjuk pada sesuatu. Semua simbol melibatkan tiga unsur, yakni simbol itu sendiri, satu rajukan atau lebih, dan hubungan antar simbol dengan rujukan. Ketiganya merupakan dasar bagi semua makna simbolik (Spradley, 1997). Teori ini mencakup bentuk-bentuk kongkrit dari perilaku individu masyarakat dalam struktur sosial yang lebih merupakan cerminan batin bukan semata dalam kaca mata perspektif modernitas dan kapitalis. Simbol-simbol dengan makna budaya yang berlaku dalam masyarakat tradisional yang belum terkontaminasi dengan budaya modern, sesungguhnya tidak relevan jika membandingkan dengan budaya Barat yang bersifat diskriminan. Pendekatan interaksionalisme simbolik pada etnoteknokonservasi burung pintar lebih difokus pada hakekat interaksi manusia dengan alam. Masyarakat lokal suku Arfak sebagai sebagai bagian dari ekosistem alam memiliki pola hidup yang dinamis. Interaksi sosial dengan masyarakat luar dan perilaku konservatif dari aktivitas berburu subsisten telah terdegradasi. Tindakan-tindakan sosial dalam masyarakat sebagai unit analisis dan sikap-sikap yang dikonstruksi dari alam dan kemudian dijadikan sebagai latar belakang menjawab permasalahan yang mereka alami telah terkontaminasi oleh perilaku konsuntif yang terkontruksi dari luar.

Interaksionalisme simbolis memandang bahwa arti dari simbol-simbol konservasi yang terbentuk sebagai hasil interaksi sosial yang berlaku dan telah membudaya dalam kehidupan masyarakat suku Arfak seharusnya tetap dipertahankan. Arti sebuah benda baik bagian tumbuhan (daun, bambu, dahan) dan hewan (bulu) merupakan wujud simbol peringatan dan larangan yang telah didefinisikan oleh komunitas masyarakat suku Arfak. Simbol benda sebagai produk interaksi sosial adalah sebuah kreatifitas individu yang terdefinisikan dengan meniru orang lain ketika dia berinteraksi (Arif, 2015; Soeprapto, 2002) (Soeprapto, 2001). Simbol-simbol tersebut selayaknya tidak disepadankan dengan makna lain, tetapi diadaptasi dengan makna asli untuk tujuan konservasi.
Simbol konservasi burung pintar (Bowerbird) di kawasan CA Pegunungan Arfak yang terus membudaya di masyarakat lokal merupakan contoh konservasi yang lebih adaptif dan mudah dipahami komunitas masyarakat suku Arfak. Kearifan lokal dalam konteks konservasi burung pintar oleh suku Arfak di CA Pegunungan Arfak dikonstruksikan melalui kajian etnosains yang bertujuan melukiskan lingkungan sebagaimana dipresepsikan oleh masyarakat. Dasar asumsinya bahwa lingkungan efektif secara obyektif dipahami oleh masyarakat lokal sebaagai tempat yang dimiliki bersama. Lingkungan efektif ini maknai dengan konsep "Igya ser hanjob". Konsep ini tidak hanya sebagai proses utama dalam pemanfaatan wilayah saja, tetapi juga melindungi SDA, Kemudian konsep ini mulai dilestarikan sebagai bagian dari cara melindungi alam dan sesamanya. Wujud simbol etno-tekno-konservasi bowerbirds sebagai tanda, batas dan larangan dalam konsep "Igya ser hanjob" terasa lebih efektif jika dibandingkan dengan simbol-simbol larangan yang dibuat oleh pemerintah (Gambar 1).

Etnoteknokonservasi burung pintar merupakan konstelasi dua paradigma yaitu faham alam (naturalist) dan faham kontruksi sosial (social contructionist). Barry (1999) dalam Awang (2006) menjelaskan bahwa faham naturalis memandang bahwa alam dan lingkungan merupakan bagian ekstenal yang memiliki tatanan tersediri di luar masyarakat. Kebijakan pengelolaan kawasan CA Pegunungan Arfak yang diambil oleh pemerintah menganut faham dalam naturalis. Faham naturalis secara tegas bersifat mekanistik (Cartesian) yang menganggap bahwa alam (termasuk hutan) terpisah dari lingkungan masyarakat bahkan terkesan kaku dengan penerapan tada-tanda larangan yang tidak menyentuh budaya masyarakat itu sendiri. Antara manusia dengan alam menganut hubungan dominasi, dimana pemerintah menganggap lebih superior (baik kekuasaan dan wewenang) dalam pengelolaan kawasan konservasi CA Pegunungan Arfak dan memisahkan dengan masyarakat lokal yang hidup didalamnya. Faham naturalis identik dengan teori etika antroposentrisme yang berpandangan bahwa hubungan manusia dengan alam hanya sebatas hubungan instrumental semata. Teori demikian bersifat egosentris karena mengutamakan kepentingan 


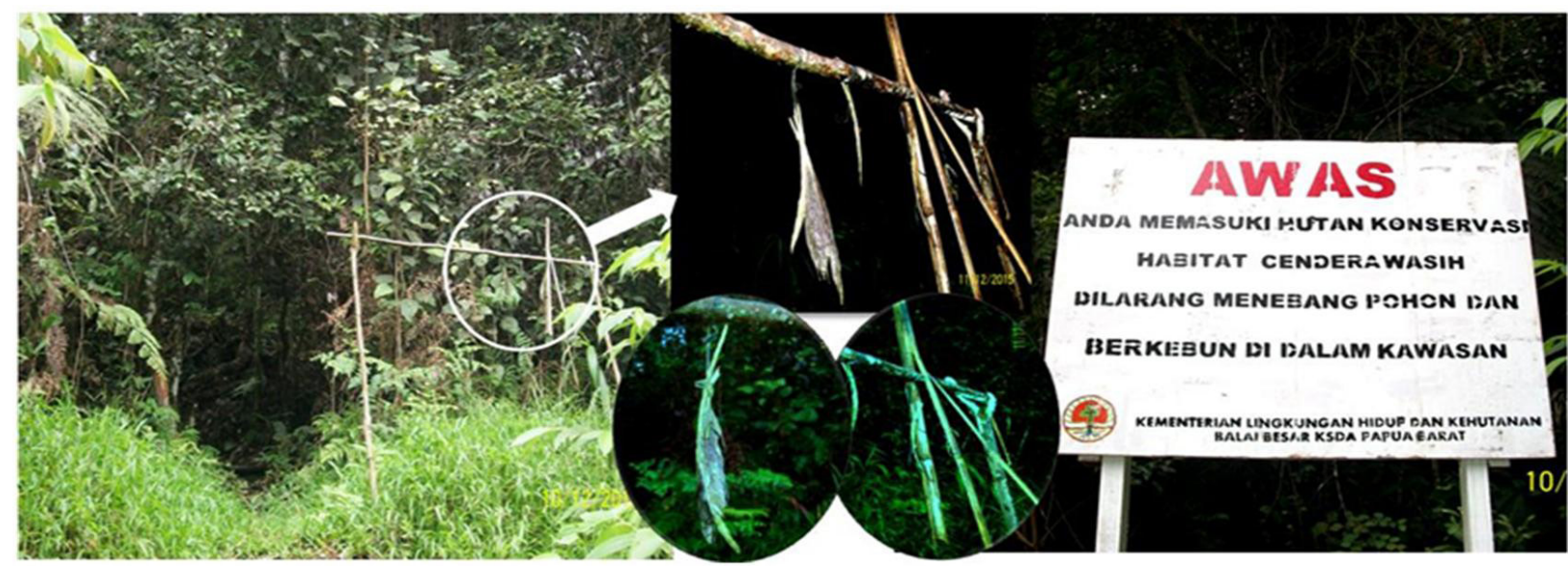

Gambar 1. Etnoteknokonervasi suku Arfak di CA Pegungan Arfak

dan tanda larangan efektif dan tanda larangan pasif yang dibuat oleh pemerintah (Dok A.Ungirwalu 2016)

manusia, sedangkan kepentingan mahluk hidup lain dan alam semesta bukan merupakan tanggungjawab moral manusia.

Etika konservasionis memandang bahwa bekerja dengan alam lebih baik dibanding mengontrol alam. Teori ini bertentangan dengan anggapan bahwa intervensi negara merupakan langkah strategis yang tepat dalam mengatur hubungan manusia dengan alam lingkungan. Intervensi negara dalam mengatur hubungan masyarakat dengan alam bersifat absolut dan dibutuhkan bila dapat disesuaikan dengan pengetahuan masyarakat melalui manajemen perencanaan partisipatif. Konsep "Igya ser Hanjob" secara spesifik dalam etnoteknokonservasi burung pintar oleh suku Arfak di Cagar Alam Pegunungan Arfak yang memandang bahwa alam (sumber daya hayati) merupakan bagian dari identitas dan entitas masyarakat arfak yang tidak dapat dipisahkan.

Alam dimana di dalamnya terdapat aktivitas dan tanggung jawab moral dalam memanfaatkan dan melestarikan sumberdaya alam hayatinya. Keraf (2010) menambahkan bahwa terdapat tanggungjawab moral terhadap mahluk hidup lain, tidak semata-mata hanya bersifat egoistik yang ditujukkan untuk kepentingan manusia. Atas dasar pandangan demikian, maka pendekatan menggunakan teori kontruksi sosial yang menfokuskan pandangannya pada hubungan internal dalam masyarakat termasuk sistem kepercayaan yang dianutnya.

Etnoteknokonservasi burung pintar dikembangkan atas dasar evaluasi subyektif dengan cara membandingkan antar perlakuan secara sederhana meskipun kadang-kadang disertai dengan informasi kuantitatif dimana sistem pengetahuan masyarakat suku Arfak berevolusi mengikuti munculnya pengalaman dan situasi baru. Penelitian etnoekologi pada dasarnya bertujuan melukiskan lingkungan sebagaimana lingkungan tersebut dilihat oleh masyarakat yang diteliti (Ahimsah-Putra \& Sri, 1985; Bennett, 2017; Ungirwalu et al., 2018). Kehadiran orang luar, khususnya para peneliti, wisatawan, LSM, dan pemerintah memberikan andil yang besar bagi perubahan evolusi paradigma berpikir masyarakat Arfak.

Kasus pembelajaran yang dialami oleh Zeth Wonggor, bahwa kehadiran David Gibs (peneliti dan pakar burung) dan para LSM (WWF dan Paradisea) turut memberikan perubahan positif terhadap perilaku seorang pemburu yang destruksif, kemudian menjadi seorang konservasionis bertugas sebagai seorang pemandu wisata yang menjadi panutan dalam menjaga, melindungi dan melestarikan burung-burung yang ada di rimba Vegelkop Pegununagn Arfak. Pengetahuan lama akan selalu diperbarui dengan pengetahuan baru, baik hasil pengamatan sendiri maupun hasil pengamatan orang lain. Pengetahuan yang kurang bermanfaat akan tergantikan oleh pengetahuan baru yang lebih bermanfaat.

Penjelasan logika ekologi yang dikembangkan melalui pengamatan dan uji coba. Masyarakat tradisional dapat menjelaskan bermacam-macam proses ekologi dan faktor-faktor yang mempengaruhinya. Walaupun tidak akurat dan kurang mendalam pada banyak kasus, namun secara umum masyarakat tradisional mampu memberikan penjelasan proses alami yang logis (Sunaryo 
\& Joshi, 2003). Karena itu kajian etnoekologi sangat dibutuhkan untuk menggali kearifankearifan lokal dalam masyarakat yang kemudian konstruksikan kembali secara sistematis dan nalar guna diadaptasikan untuk mengelola summberdaya alam secara lestari.

\section{B. Habitat dan Simbolisme Bowerbird}

Hutan di wilayah kepala burung (Vogelkop) yang terletak di semenanjung Domberai mencakup pegunungan Tambrauw dan Arfak dikenal sebagai habitat berbagai flora dan fauna endemik dan khas (Pratt et al., 2014). Salah satu fauna endemik khas pegunungan Arfak adalah burung pintar dengan spesies Amblyornis inornata. Beberapa istilah burung pintar diantaranya Namdur atau Bowerbird. Sementara untuk bahasa lokal disebut dengan Mbrecew untuk jenis burung jantan dan Urinyai untuk jenis burung betina. Penyebutan burung pintar (Bowerbird) yang diberikan oleh masyarakat lokal Arfak karena spesies burung ini memiliki keunikan dan kecerdasan dalam mengkonstruksi sarang berdasarkan meterial dan warna sebagai bahan penyusunnya.

Ketangkasan dan keahlian pembuatan saran terletak pada ketangguhan burung pintar jenis jantan dalam membangun sebuah sarang terproyeksi pada hasil arsitektur sarang yang tersusun atas ranting pilihan berwarna kecoklatan, dan dikonstruksi dengan pola melengkung. Susunan ranting terletak berselang seling dan saling berimpitan sehingga kontruksi sarang menjadi kokoh tanpa ada simpul ikatan. Dalam penelitian, Tim peneliti mencatat sebanyak 9 (sembilan) persarangan burung pintar pada lokasi pengamatan. Proses pembangunan sarang membutuhkan waktu berkisar antara 9 sampai 18 bulan. Tidak hanya bentuk struktur dan gaya arsitektur sarang yang unik, halaman di depan sarang juga dihiasi dengan berbagai ornamen material berwarna kontras yang dikumpulkan dan ditumpuk menurut warna sejenis yang serasi (Gambar 2).

Habitat burung pintar berada pada hutan dataran tinggi di wilayah CA Pegunungan Arfak, pada elevasi 1200-1600 meter di atas permukaan laut (DPL). Burung pintar jantan (Mbrecew) dalam membangun persarangannya yang khas dengan arsitektur yang indah sebagai sebuah istana pada saat musim perkawinan (mating season). Proses pembangunan sarang dilakukan secara bertahap. Burung pintar jantan dalam mengkontruksi sarang sering melakukan atraksi untuk mendemonstraksikan keperkasaan dan keahliannya kepada burung pintarbetina(Urinyai).Urinyaiselalumengamati sang jantan secara sembunyi-sembunyi selama proses pembuatan persarangan berlangsung. Proses ini adalah salah satu bentuk interaksi dan komunikasi sang jantan untuk memikat sang betina yang menjadi daya tarik tersendiri khususnya bagi wisata pengamatan burung.

Interaksi burung pintar jantan dalam berkomunikasi dengan betinanya, umumnya diawali dengan memperagakan gerak tubuh yang indah dan diterjemahkan sebagai suatu "tarian" sebagi pengikat daya tarik betina sambil menyusun dan menunjukan satu persatu bahan alam (beraneka buah, bunga, bijibijian dan ranting) di sekitar persarangannya. Bahan-bahan tersebut diletakan secara teratur menurut warna sejenis per tumpukkan, yang pada akhirnya menyerupai suatu arah jalan menuju ke persarangan. Struktur dan arsitektur persarangan sebagian besar terbuat dari bahan tumbuhan yang ada dalam radius jangkauan kekuasaan burung pintar jantan. Tarian dan persarangan menjadi simbol kekhasan dan
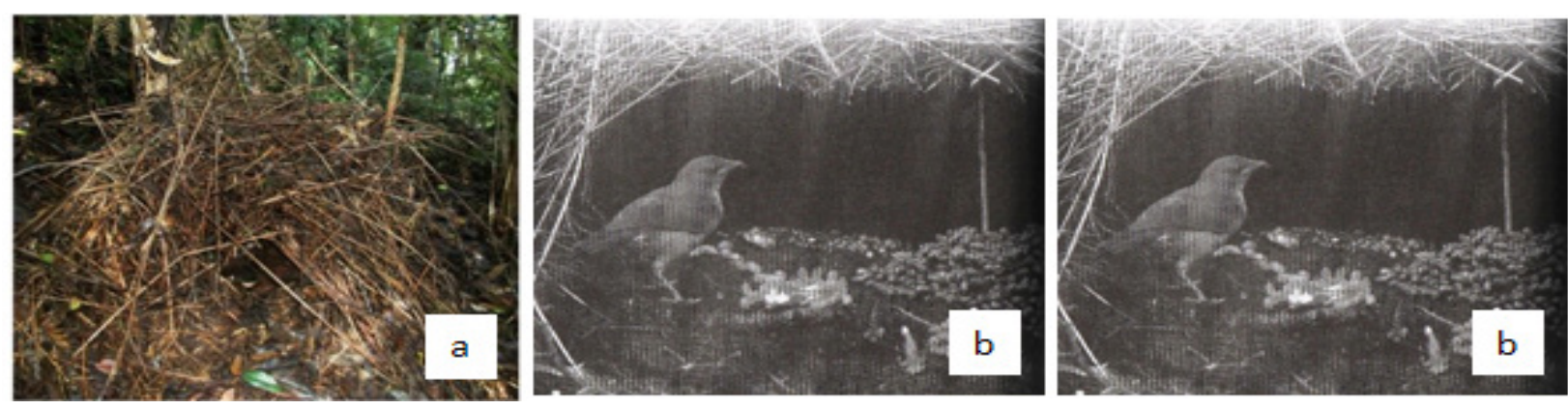

Gambar 2. Konstruksi dan arsitektur sarang burung pintar (Dok U. Agutono, 2014)

(a. persarangan non aktif, b dan c. persarangan aktif) 
keunikan burung pintar di puncak Urong Gunung Konghoi Mokwam sebagai salah satu wilayah kawasan CA Pegunungan Arfak.

Interaksi masyarakat dengan lingkungan sumber daya hayati secara khusus terhadap pemanfaatan dan pelestarian wisata burung pintar dalam konstruksi sosial menghasilkan pengalaman sebagai akibat dari ditemuinya fenomena-fenomena alam yang terjadi secara berulang. Pengalaman tersebut diceritakan secara turun-temurun dan diakui kebenarannya oleh masyarakat sehingga menjadi tradisi. Tradisi-tradisi tersebut diwujudkan dalam bentuk kegiatan-kegiatan dan atau ritualritual dan diyakini memiliki nilai-nilai yang harus dipatuhi dalam kehidupan sosial mereka. Tradisi-tradisi yang telah melembaga dalam kehidupan bermasyarakat suatu komunitas etnis tertentu, menghasilkan nilainilai budaya sebagai dasar gerak langkah mereka dalam mengelola dan memanfaatkan sumberdaya alam dalam wilayahnya. Dalam interaksi tersebut terkandung pengatahuan tradisonal yang telah dikenal secara turuntemurun (Ungirwalu et al., 2018). Pengetahuan tradisional semakin adaptif dan dihargai sebagai salah satu komponen utama dalam pendekatan konservasi modern saat ini (Liu et al., 2010).

\section{KESIMPULAN}

Kearifan lokal dalam konteks konservasi lokal terhadap perlindungan burung pintar oleh suku Arfak di CA Pegunungan Arfak dikonstruksikan dari lingkungan yang efektif dan secara obyektif dipahami oleh masyarakat lokal yang merupakan bagian dari interaksi dan adaptasi dengan lingkungannya Kearifan lokal dalam pemanfaatan dan pelestarian burung pintar merupakan proses kreasi sosial. Adaptasi kreasi sosial masyarakat suku Arfak terhadap lingkungan akan menghasilkan bentuk-bentuk interaksi yang pada awalnya berfokus pada pemanfaatan bagi pemenuhan subsisten, kemudian beralih menjadi konsep pelestarian lokal dalam wujud simbol larangan berupa bagian tubuh hewan dan tumbuhan yang dipengaruhi oleh perubahan lingkungan alam dan kehadiran pihak luar (peneliti, wisatawan, LSM dan pemerintah) dalam menentukan perubahan terhadap pelestarian burung pintar. Simbolisasi tanda larangan merupakan wujud etnoteknokonservasi suku Arfak dalam mendukung konsep "Igya ser Hanjob" yaitu menjaga batas keberadaan burung pintar di kawasan CA Pegunungan Arfak sebagai identitas dan entitasnya yang masih dipertahankan hingga sekarang.

\section{UCAPAN TERIMA KASIH}

Kepala Badan Pengendalian Lingkungan Hidup Provinsi Papua Barat, bapak Zeth Wonggor dan warga masyarakat di Mokwam. Terima kasih ditujukan kepada bapak Edi Sumarmo, Ugi Agustono dan Timoti Laman atas kontribusi pemikirannya hingga tulisan ini dapat dilengkapi dengan data pendukung dan gambar yang komprehensif. Paper ini telah dipresentasikan sebagai salah satu poster ilmiah dalam kegiatan ICBE tahun 2016 di Jayapura.

\section{Daftar Pustaka}

Agustono, U. (2014). Biografi Zeth Wonggor Pergulatan Hidup Sang Pemburu Bidadari Arfak. Medium.

Ahimsah-Putra, \& Sri, H. (1985). Etnosains dan Etnometodologi: Sebuah Perbandingan dalam Masyarakat Indonesia (Cetakan ke). LIPI Press.

Arif, S. (2015). Interaksionisme Simbolik: Perspektif Sosiologi Modern. Avepress. Com; avepress.com. https://www. avepress.com/interaksionisme-simbolikperspektif-sosiologi-modern/

Awang, S. A. (2006). Sosiologi Pengetahuan Deforestasi: Konstruksi Sosial dan Perlawanan. Debut Press.

Bennett, J. W. (2017). The Ecological Transition: Cultural Anthropology and Human Adaptation. Routledge.

Conklin, H. C. (1955). Hanunóo Color Categories. Journal of Anthropological Research, 42(3), 441-446. https://doi. org $/ 10.2307 / 3630047$

Frake, C. O. (1968). Readings in the Sociology of Language. In J. A. Fishman (Ed.), Readings in the Sociology of Language. DE GRUYTER. https://doi. org/10.1515/9783110805376

Geertz, C. (1983). Involusi Pertanian: Proses Perubahan Ekologi di Indonesia. Bhratara Karya Aksara.

Kaplan, D., \& Manners, A. A. (1999). Teori budaya. Pustaka Pelajar. 
Karpouzoglou, T., \& Zimmer, A. (2016). Ways of knowing the wastewaterscape: Urban political ecology and the politics of wastewater in Delhi, India. Habitat International, 54(2), 150-160. https://doi. org/10.1016/j.habitatint.2015.12.024

Keraf, A. S. (2010). Etika lingkungan hidup. Penerbit Buku Kompas.

Laksono, P. M., Rianty, A., Hendrijani, A. B., Gunawan, Mandacan, A., \& Mansoara, N. (2004). Igya Ser Hanjop : Masyarakat Arfak dan Konsep Konservasi. Pusat Studi Asia Pasifik, Universitas Gadjah Mada.

Leopold, A. C. (2004). Living with the Land Ethic. BioScience, 54(2), 149154. https://doi.org/10.1641/00063568(2004)054[0149:Iwtle]2.0.co;2

Liu, J., Ouyang, Z., \& Miao, H. (2010). Environmental attitudes of stakeholders and their perceptions regarding protected area-community conflicts: A case study in China. Journal of Environmental Management, 91(11), 2254-2262. https:// doi.org/10.1016/j.jenvman.2010.06.007

Mansoben,J.R. (1995).Sistem Politik Tradisional di Irian Jaya. LIPI-RUL.

Pratt, T. K., Beehler, B. M., Bishop, K. D., Coates, B. J., Diamond, J. M., Lecroy, M., Anderton, J., Coe, J., \& Zimmerman, D. A. (Dale A. (2014). Birds of New Guinea (2nd, direvisi ed.). Princeton University Press.
Radcliffe-Brown, A. R. (2008). Structure and Function in Primitive Society: Essays and Addresses (cetak ulang). Free Press.

Rudito, B., \& Famiola, M. (2008). Social Mapping: Metode Pemetaan Sosial: Teknik Memahami Suatu Masyarakat atau Komuniti. Rekayasa Sains.

Soeprapto, R. (2002). Interaksionisme Simbolik: Perspektif Sosiologi Modern. Averroes Press dan Pustaka Pelajar.

Spradley, J. P. (1997). Metode Etnografi . (Edisi kedua). Tiara Wacana.

Steward, J. H. (1936). The Economic and Social Basis of Primitive Bands. https:// books.google.co.id/books/about/The Economic_and_Social_Basis_of_Primiti. html?id=pH02nQEACAAJ\&redir_esc $=y$

Sunaryo, \& Joshi, L. (2003). Peranan Pengetahuan Ekologi Lokal dalam Sistem Agroforestri. In Bahan Ajaran Agroforestri (Bahan Ajar, p. 40). World Agroforestry Centre (ICRAF). http://old. worldagroforestry.org/sea/Publications/ files/lecturenote/LN0007-04.pdf

Ungirwalu, A., Awang, S. A., \& Togede, M. J. (2018). Etnobotani Buah Hitam: Konstruksi Etnoekologi Etnis Wandamen-Papua. Deepublish. 